\title{
PENTINGNYA PERENCAAN ASUHAN KEPERAWATAN DALAM MEMBERI ASUHAN KEPERAWATAN DI RUMAH SAKIT
}

\section{Hanita Grace Sagala hanitagrace10@gmail.com}

\begin{abstract}
ABSTRAK
Perawat profesional bertanggung jawab dan dapat diandalkan untuk menyusun rencna asuhan keperawatan. Idealnya, perawat primer, manajer kasus, atau perawat yang bertanggung jawab terhadap perawatan yang bersinambungan melengkapi rencana asuhan klien. Banyak implikasi yang dibuat dalam menusun suatu rencana. Pengkajian yang akurat dan multiforal adalah landasan rencana yang penting. Dalam menentukan tahap perencanaan bagi perawat diperlukan berbagai pengetahuan dan keterampilan diantaranya pengetahuan tentang kekuatan dan kelemahan klien, nilai dan kepercayaan klien, batasan praktek keperawatan, peran dari tenaga kesehatan lainnya , kemampuan dalam memecahkan masalah, mengambil keputusan, menulis tujuan serta memilih dan membuat strategi keperawatan yang aman dalam memenuhi tujuan, menulis instruksi keperawatan serta kemampuan dalam melaksanakan kerja sama dengan tingkat kesehatan lain.
\end{abstract}

Kata kunci : Perencanaan keperawatan. Asuhan keperawatan

LATAR BELAKANG

Proses keperawatan adalah aktivitas yang mempunyai maksud yaitu praktik keperawatan yang dilakukan dengan cara yang sistematik. Selama melaksanakan proses keperawatan, perawat menggunakan dasar pengetahuan yang komprehensif untuk mengkaji status kesehatan klien, membuat penilaian yang bijaksana dan mendiagnosa, mengidentifikasi hasil akhir kesehatan klien dan merencanakan, menerapkan dan mengevaluasi tindakan keperawatan yang tepat guna mencapai hasil akhir tersebut (Dermawan, 2012).
Secara sederhana, rencana keperawatan dapat diartikan sebagai suatu dokumen tulisan tangan dalam menyelesaikan masalah, tujuan, dan intervensi keperawatan. Sebagai mana disebutkan sebelumnya, rencana keperawatan merupakan metode komunikasi tentang asuhan keperawatan kepada klien. Setiap klien memerlukan asuhan keperawatan perlu suatu perencanaan yang baik.

Tahap perencanaan merupakan suatu proses penyusunan berbagai intervensi keperawatan yang dibutuhkan untuk mencegah, menurunkan atau 
mengurangi masalah-masalah klien. Perencanaan ini merupakan langkah ketiga dalam membuat suatu proses keperawatan. Dalam menentukan tahap perencanaan bagi perawat diperlukan berbagai pengetahuan dan keterampilan diantaranya pengetahuan tentang kekuatan dan kelemahan klien, nilai dan kepercayaan klien, batasan praktek keperawatan, peran dari tenaga kesehatan lainnya , kemampuan dalam memecahkan masalah, mengambil keputusan, menulis tujuan serta memilih dan membuat strategi keperawatan yang aman dalam memenuhi tujuan, menulis instruksi keperawatan serta kemampuan dalam melaksanakan kerja sama dengan tingkat kesehatan lain.

Rencana tindakan medis biasanya difokuskan pada kegiatan yang berhubungan dengan diagnostik dan pengobatan berdasarkan kondisi klien. Tindakan tersebut didelegasikan kepada perawat dan tenaga kesehatan lainnya. Tindakan medis sering meliputi pengobatan, uji diagnostik, diet dan pemberian obat.

\section{TUJUAN}

Tujuan dibuatnya kajian ini adalah untuk menambah wawasan kepada pembaca tentang dokumentasi asuhan keperawatan.

\section{METODE}

Metode dalam penulisan ini dilakukan dengan mengumpulkan data dari buku, jurnal, dan thesis dan e-book, kemudian melakukan analisis secara mendalam terkait topik yang dibahas, serta bersifat subjektif yaitu proses penulisan yang lebih fokus pada landasan teori. Dan melakukan analisis buku dan e-jurnal yang relevan dan berfokus kepada pengaplikasian berfikir kritis dalam mengelola informasi dan komunikasi keperawatan. Adapun ejurnal yang digunakan ini adalah dengan menggunakan google dengan memasukkan kata kunci “ Konsep Dasar Keperawatan”. Jurnal yang digunakan adalah jurnal yang diterbitkan 8 tahun terakhir. Adapun referensi akan dicantumkan dalam penulisan ini dengan jelas terdapat pada daftar pustaka pada bagian akhir penulis.

\section{HASIL}

Rencana asuhan berfungsi sebagai sarana utama untuk meningkatkan pendekatan asuhan keperawatan yang individual dan konsisten. Melalui dokumentasi masalah utama klien dan melalui rencana untuk mengurangi atau memodifikasi masalah, perawat memfasilitasi koordinasi seluruh anggota tim tim perawat kesehatan. Jika rencana tertulis berdasarkan panduan yang dianjurkan maka tujuan jangka panjang dan jangka pendek memberikan arahan perawatan yang diinginkan dan menjadi 
landasan akhir evaluasi. Selain itu, strategi dan intervensi keperawatan memandu dan mengoordinasi klien, perawat, dan individu lain dalam tindakan mereka untuk meningkatkan pencapaian hasil. Rencana asuhan yang lengkap perlu digunakan untuk memnuhi tujuan ini. Rencana yang disusun dengan baik trial and error yang menghabiskan banyak waktu, menghindari duplikasi upaya, dan menurunkan kegagalan perawatan yang mahal dan membutuhkan banyak waktu.

Perawat profesional bertanggung jawab dan dapat diandalkan untuk menyusun rencna asuhan keperawatan. Idealnya, perawat primer, manajer kasus, atau perawat yang bertanggung jawab terhadap perawatan yang bersinambungan melengkapi rencana asuhan klien. Banyak implikasi yang dibuat dalam menusun suatu rencana. Pengkajian yang akurat dan multiforal adalah landasan rencana yang penting. Diagnosis keperawatanberkembang dari analisis dan sintesis data, yang membutuhkan dasar pengetahuan yang komperehensif dankemampuan berpikir kritis. Diagnosis diurutkan berdasarkan prioritas intervensi, tujuan jangka panjang, yang ditetapkan, tujuan jangka pendek yang disusun, strategi yang diidentifikasi, dan intervensi keperawatan yang diuraikan dengan menggunakan rsional ilmiah. Anggotatim lainnya dapat memberikan input dan umpan balik mengenai pendekatan kepada klien, tetapi perawat profesional bertanggung jawab terhadap penyusunan asuhan keperawatan tersebut.

Tujuan rencana tindakan dibagi menjadi dua menurut Dermawan (2012) yaitu:

- Tujuan administratif

1. Untuk mengidentifikasi fokus keperawatan kepada pasien atau kelompok.

2. Untuk membedakan tanggungjawab perawat dengan profesi kesehatan lainnya.

3. Untuk menyediakan suatu kriteria guna pengulangan dan evaluasi keperawatan.

- Tujuan klinik

1. Menyediakan suatu pedoman dalam penulisan.

2. Mengkomunikasikan dengan staf perawat; apa yang diajarkan, diobservasi dan dilaksanakan.

3. Rencana tindakan yang spesifik secara langsung bagi individu, keluarga, dan tenaga kesehatan lainnya untuk melaksanakan tindakan.

\section{PEMBAHASAN}

1) Pengertian perencanaan

keperawatan

Perencanaan keperawatan adalah suatu proses di dalam pemecahan masalah yang merupakan keputusan awal tentang sesuatu apa yang akan dilakukan, bagaimana 
dilakukan, kapan dilakukan, siapa yang melakukan dari semua tindakan keperawatan (Dermawan, 2012).

Perencanaan keperawatan adalah rencana tindakan keperawatan tertulis yang menggambarkan masalah kesehatan pasien, hasil yang akan diharapkan, tindakan-tindakan keperawatan dan kemajuan pasien secara spesifik (Manurung, 2011).

Perencanaan keperawatan adalah bagian dari fase pengorganisasian dalam proses keperawatan sebagai pedoman untuk mengarahkan tindakan keperawatan dalam usaha membantu, meringankan, memecahkan masalah atau untuk

b) Tujuan klinik

(1) Menyediakan suatu pedoman dalam penulisan.

(2) Mengkomunikasikan dengan staf perawat; apa yang diajarkan, diobservasi dan dilaksanakan.

(3) Rencana tindakan yang spesifik secara langsung bagi individu, keluarga, dan tenaga kesehatan lainnya untuk melaksanakan tindakan.

3) Langkah - langkah perencanaan keperawatan

Langkah - langkah perencanaan keperawatan menurut Manurung (2011) adalah sebagai berikut:
a) Menentukan
prioritas

memenuhi kebutuhan pasien (Setiadi, 2012).

\section{2) Tujuan perencanaan keperawatan}

Tujuan rencana tindakan dibagi menjadi dua menurut Dermawan (2012) yaitu:

a) Tujuan administratif

(1) Untuk mengidentifikasi fokus keperawatan kepada pasien atau kelompok.

(2) Untuk membedakan tanggungjawab perawat dengan profesi kesehatan lainnya.

(3) Untuk menyediakan suatu kriteria guna pengulangan dan evaluasi keperawatan.

(4) Untuk menyediakan kriteria klasifikasi pasien. Prioritas keperawatan adalah penyusunan diagnosa keperawatan atau masalah pasien dengan menggunakan tingkat kedaruratan atau kepentingan untuk memperoleh tahapan intervensi keperawatan yang dibutuhkan.

Saat menentukan prioritas diagnosa keperawatan digunakan standar prioritas kebutuhan dari Maslow, sebagai berikut : Prioritas 1 : masalah yang berhubungan dengan kebutuhan fisiologis seperti respirasi sirkulasi, nutrisi, hidrasi, eliminasi, suhu dan kesenjangan fisik.

Prioritas 2 : masalah yang berpengaruh pada keselamatan dan keamanan.

masalah. 
Prioritas 3 : masalah yang berpengaruh terhadap cinta dan rasa memiliki.

Prioritas 4 : masalah yang berpengaruh pada rasa harga diri. Prioritas 5 : masalah yang berpengaruh pada kemampuan mencapai sasaran pribadi atau aktualisasi diri.

Pengurutan prioritas akan dipengaruhi oleh faktor- faktor persepsi pasien terhadap prioritas, untuk itu menanyakan kepada pasien tentang apa yang dirasakannya merupakan hal yang penting.

b) Menuliskan tujuan dan kriteria hasil.

Tujuan perawatan adalah hasil yang diinginkan dari asuhan keperawatan yang diharapkan dapat dicapai bersama pasien serta direncanakan untuk mengurangi masalah yang telah diidentifikasi dalam diagnosis keperawatan (Manurung, 2011). Saat merumuskan tujuan, ada beberapa petunjuk umum yang perlu diperhatikan menurut Manurung (2011), yaitu :

(1) Tujuan dinyatakan dengan istilah hasil yang ingin dicapai, bukan tindakan keperawatannya.

(2) Tujuan keperawatan harus menggambarkan perilaku pasien yang dapat diamati dan diukur.

(3) Tujuan harus realistis, mencerminkan kemampuan dan keterlibatan pasien.

(4) Setiap tujuan berdasarkan dari satu diagnosis keperawatan.
Kriteria hasil mempunyai ciri-ciri menurut Dermawan (2012) yaitu setiap kriteria hasil berhubungan dengan tujuan yang telah ditetapkan, hasil yang ditetapkan dalam kriteria hasil, memungkinkan untuk dicapai, setiap kriteria hasil adalah pernyataan satu hal yang spesifik, kriteria harus sekonkrit mungkin untuk memudahkan pengukuran, kriteria cukup besar atau dapat diukur, kriteria menggunakan kata-kata positif bukan menggunakan kata negatif.

Pedoman penulisan kriteria hasil menurut Setiadi (2012) adalah berfokus pada pasien, singkat dan jelas, dapat diobservasi dan dapat diukur, ada batas waktu, ditentukan oleh perawat dan pasien.

c) Memilih rencana tindakan atau intervensi keperawatan.

(1) Tindakan keperawatan harus aman bagi pasien.

(2) Tindakan keperawatan harus sejalan dengan tindakan pengobatan.

(3) Tindakan keperawatan harus didasari prinsip dan pengetahuan yang digabungkan dari pendidikan dan pengalaman sebelumnya.

(4) Tulis sekumpulan tindakan keperawatan untuk mencapai setiap tujuan. (5) Pilih satu kumpulan tindakan keperawatan yang kiranya cocok dengan sikap yang disebutkan dalam pernyataan tujuan. 
(6) Tindakan keperawatan harus realistis.

(7) Tindakan keperawatan harus penting bagi peningkatan kesehatan pasien dan sejalan dengan tujuan serta nilai perseorangan pasien.

(8) Gunakan pasien sebagai sumbersumber dalam memilih tindakan keperawatan.

(9) Tulis tindakan keperawatn secara berurutan.

d. Implementasi keperawatan

1) Pengertian implementasi

keperawatan

Implementasi keperawatan adalah pelaksanaan rencana keperawatan oleh perawat dan pasien (Riyadi, 2010).

Implementasi keperawatan adalah pengelolaan dan perwujudan dari rencana keperawatan yang telah disusun pada tahap perencanaan (Setiadi, 2012).

2) Pedoman implementasi keperawatan

Pedoman implementasi keperawatan menurut Dermawan (2012) sebagai berikut:

a) Tindakan yang dilakukan konsisten dengan rencana dan dilakukan setelah memvalidasi rencana.

Validasi menentukan apakah rencana masih relevan, masalah mendesak, berdasar pada rasional yang baik dan diindividualisasikan. Perawat memastikan bahwa tindakan yang sedang diimplementasikan, baik oleh pasien, perawat atau yang lain, berorientasi pada tujuan dan hasil. Tindakan selama implementasi diarahkan untuk mencapai tujuan.

b) Keterampilan interpersonal, intelektual dan teknis dilakukan dengan kompeten dan efisien di lingkungan yang sesuai.

Perawat harus kompeten dan mampu melaksanakan keterampilan ini secara efisien guna menjalankan rencana. Kesadaran diri dan kekuatan serta keterbatasan perawat menunjang pemberian asuhan yang kompeten dan efisien sekaligus memerankan peran keperawatan profesional.

c) Keamanan fisik dan psikologis pasien dilindungi.

Selama melaksanakan implementasi, keamanan fisik dan psikologis dipastikan dengan mempersiapkan pasien secara adekuat, melakukan asuhan keperawatan dengan terampil dan efisien, menerapkan prinsip yang baik, mengindividualisasikan tindakan dan mendukung pasien selama tindakan tersebut.

d) Dokumentasi tindakan dan respon pasien dicantumkan dalam catatan perawatan kesehatan dan rencana asuhan.

Dokumentasi dalam catatan perawatan kesehatan terdiri atas deskripsi tindakan yang diimplementasikan dan respon pasien terhadap tindakan tersebut. Tindakan yang 
tidak diimplementasikan juga dicatat disertai alasan. Dokumentasi rencana asuhan untuk meningkatkan kesinambungan asuhan dan untuk mencatat perkembangan pasien guna mencapai kriteria hasil.

$$
\text { e. Evaluasi keperawatan }
$$

1) Pengertian evaluasi keperawatan

Evaluasi keperawatan adalah mengkaji respon pasien setelah dilakukan intervensi keperawatan dan mengkaji ulang asuhan keperawatan yang telah diberikan (Deswani, 2009).

Evaluasi keperawatan adalah kegiatan yang terus menerus dilakukan untuk menentukan apakah rencana keperawatan efektif dan bagaimana rencana keperawatan dilanjutkan, merevisi rencana atau menghentikan rencana keperawatan (Manurung, 2011).

\section{2) Penilaian keberhasilan}

Penilaian adalah tahap yang menentukan apakah tujuan tercapai. Evaluasi selalu berkaitan dengan tujuan, apabila dalam penilaian ternyata tujuan tidak tercapai, maka perlu dicari penyebabnya. Hal tersebut dapat terjadi karena beberapa faktor :
a) Tujuan tidak realistis.
b) Tindakan keperawatan yang tidak tepat.

c) Terdapat faktor lingkungan yang tidak dapat diatasi.
Alasan pentingnya penilaian sebagai berikut :

a) Menghentikan tindakan atau kegiatan yang tidak berguna.

b) Untuk menambah ketepatgunaan tindakan keperawatan.

c) Sebagai bukti hasil dari tindakan perawatan.

d) Untuk pengembangan dan penyempurnaan praktik

keperawatan.

3) Tipe pernyataan evaluasi

Tipe pernyataan evaluasi menurut Setiadi (2012) sebagai berikut:

Tipe pernyataan tahapan evaluasi dapat dilakukan secara formatif dan sumatif. Evaluasi formatif adalah evaluasi yang dilakukan selama proses asuhan keperawatan, sedangkan evaluasi sumatif adalah evaluasi akhir.

a) Pernyataan evaluasi formatif.

Hasil observasi dan analisa perawat terhadap respon pasien segera pada saat atau setelah dilakukan tindakan keperawatan dan ditulis pada catatan perawatan.

b) Pernyataan evaluasi sumatif.

Rekapitulasi dan kesimpulan dari observasi dan analisa status kesehatan sesuai waktu pada tujuan dan ditulis pada catatan perkembangan.

4) Bentuk evaluasi

Bentuk evaluasi menurut Deswani (2009) sebagai berikut: 
a) Evaluasi struktur.

Evaluasi struktur difokuskan pada kelengkapan tata cara atau keadaan sekeliling tempat pelayanan keperawatan diberikan. Aspek lingkungan secara langsung atau tidak langsung mempengaruhi dalam pemberian pelayanan.

b) Evaluasi proses.

Evaluasi proses berfokus pada penampilan kerja perawat dan apakah perawat dalam memberikan pelayanan keperawatan merasa cocok, tanpa tekanan, dan sesuai wewenang.

c) Evaluasi hasil.

Evaluasi hasil berfokus pada respon dan fungsi pasien. Respon perilaku pasien merupakan pengaruh dari intervensi keperawatan dan akan terlihat pada pencapaian tujuan dan kriteria hasil.

4. Manfaat kegunaan proses keperawatan

Manfaat kegunaan proses keperawatan menurut Dermawan (2013) adalah sebagai berikut:

a. Manfaat untuk pasien

1) Mendapatkan pelayanan asuhan keperawatan yang bermutu, efektif dan efisien.

2) Pasien bebas mengemukakan pendapat tentang kebutuhannya untuk mempercepat penyembuhan.

3) Proses penyembuhan dapat dipercaya dan pasien mendapat kepuasan. b. Manfaat untuk tenaga keperawatan 1) Kemampuan intelektual dan teknis tenaga keperawatan dapat berkembang meliputi kemampuan berfikir kritis analitis maupun kemampuan keterampilan teknis.

2) Meningkatkan kemandirian perawat.

3) Kepuasan yang dirasakan pasien akan meningkatkan citra perawat dimata masyarakat.

c. Manfaat untuk institusi kesehatan

1) Banyak pasien sehingga pembiayaan meningkat, yang akan berdampak pada peningkatan mutu pelayanan dan kesejahteraan tenaga kesehatan.

2) Citra rumah sakit bertambah dimata masyarakat.

d. Manfaat untuk masyarakat Masyarakat akan memperoleh pelayanan kesehatan yang bermutu dan berkualitas.

Perawat dalam mengelola asuhan keperawatan dan diagnosa keperawatan harus memiliki kompetensi.

\section{PENUTUP}

Tahap perencanaan merupakan suatu proses penyusunan berbagai intervensi keperawatan yang dibutuhkan untuk mencegah, menurunkan atau mengurangi masalah-masalah klien. 
Perencanaan ini merupakan langkah ketiga dalam membuat suatu proses keperawatan. Dalam menentukan tahap perencanaan bagi perawat diperlukan berbagai pengetahuan dan keterampilan diantaranya pengetahuan tentang kekuatan dan kelemahan klien, nilai dan kepercayaan klien, batasan praktek keperawatan, peran dari tenaga kesehatan lainnya , kemampuan dalam memecahkan masalah, mengambil keputusan, menulis tujuan serta memilih dan membuat strategi keperawatan yang aman dalam memenuhi tujuan, menulis instruksi keperawatan serta kemampuan dalam melaksanakan kerja sama dengan tingkat kesehatan lain.

Rencana tindakan medis biasanya difokuskan pada kegiatan yang berhubungan dengan diagnostik dan pengobatan berdasarkan kondisi klien. Tindakan tersebut didelegasikan kepada perawat dan tenaga kesehatan lainnya. Tindakan medis sering meliputi pengobatan, uji diagnostik, diet dan pemberian obat.

\section{DAFTAR PUSTAKA}

Agustin, R. (2017). Optimalisasi Pelaksanaan Discharge Planning melelui Pengembangan

Model Discharge Planning Terintegrasi Pelayanan Keperawatan. Jurnal Keperawatan Muhammadiyah, 2, 91-99.
Aini, D. N. (2018). Hubungan Kualitas Pelayanan Keperawatan dengan Tingkat Kepuasan

Pasien Rawat Inap di RSUD DR. H. SOEWONDO KENDAL. Jurnal Ners Widya Husada Semarang, 2.

Butar-Butar, J., \& Simamora, R. H. (2016). Hubungan Mutu Pelayanan Keperawatan dengan Tingkat Kepuasan Pasien Rawat Inap di RSUD Pandan Kabupaten Tapanuli Tengah. Jurnal Ners Indonesia, 6(1), 50-63.

Dewan Pengurus Pusat Persatuan Perawat Nasional Indonesia. (2019). Pedoman Penelitian Keperawatan Indonesia Peraturan Menteri Kesehatan Republik Indonesia Nomor 82. (2013). Sistem Informasi Manajemen Rumah Saki.

Hariyati, R. T. S. (2012). Optimalisasi Kinerja Sistem Informasi Manajemen Keperawatan Berbasis Model Simpro. (Unpublished doctoral dissertation thesis). Universita Indonesia Jakarta.

Hasbi, F. H. (2012). Analisis Hubungan Persepsi Pasien tentang Mutu Pelayanan dengan Pemanfaatan Ulang Pelayanan Rawat Jalan Puskesmas Poncol Kota Semarang. Jurnal Kesehatan Masyarakat Universitas Diponegoro, 1.

Hidayat, A.A. A. (2007). Metode Penelitian dan Tehnik Analisis Data. 
Penerbit Salemba Medika. Edisi pertama . Jakarta.

Murtiono, G. K. (2020). Gambaran asuhan keperawatan pada asien hipertensi dengan ganguuan kebutuhanrasa nyaman nyeri. $13(1) ; 35-42$

Purnamasari, L. D., \& Ropyanto, C. B. (2012). Evaluasi Pelaksanaan Perencanaan Pulang.

Jurnal Keperawatan Diponegoro, 1, 213218.

Setiati S, Alwi I, Sudoyo AW, K MS, Setiyohadi B, Syam AF. Buku Ajar Ilmu Penyakit Dalam. Jilid II. Interna Publishing; 2015.

Simamora, R. H. (2005). Hubungan Persepsi Perawat Pelaksana Terhadap Penerapan Fungsi Pengorganisasian Yang Dilakukan Oleh Kepala Ruangan Dengan Kinerjanya Diruang Rawat Inap RSUD Koja Jakarta Utara (Doctoral dissertation, Tesis FIK UI, Tidak dipublikasikan). 